Article

\title{
New Vulnerabilities for Migrants and Refugees in State Responses to the Global Pandemic, COVID-19
}

\author{
Claudia Tazreiter ${ }^{1, *}$ and Simon Metcalfe ${ }^{2}$ \\ 1 Department of Culture and Society (IKOS), Division of Migration, Ethnicity and Society (REMESO), \\ Linköping University, 58183 Linköping, Sweden \\ 2 Research Assistant, Forced Migration Research Network, University of New South Wales, \\ Sydney 2052, Australia; simonm2012@gmail.com \\ * Correspondence: claudia.tazreiter@liu.se
}

\section{check for}

updates

Citation: Tazreiter, Claudia, and Simon Metcalfe. 2021. New

Vulnerabilities for Migrants and Refugees in State Responses to the Global Pandemic, COVID-19. Social Sciences 10: 342. https://doi.org/ 10.3390/socsci10090342

Academic Editors: Linda Briskman and Lucy Fiske

Received: 21 May 2021

Accepted: 6 September 2021

Published: 14 September 2021

Publisher's Note: MDPI stays neutral with regard to jurisdictional claims in published maps and institutional affiliations.

Copyright: (c) 2021 by the authors. Licensee MDPI, Basel, Switzerland. This article is an open access article distributed under the terms and conditions of the Creative Commons Attribution (CC BY) license (https:/ / creativecommons.org/licenses/by/ $4.0 /)$.

\begin{abstract}
This article examines the global pandemic, COVID-19, through the lens of responses to vulnerable migrants, asking what state responses mean for the future of human rights values and for humanitarian interventions. The responses of the Australian state are developed as a case study of actions and policies directed at refugees and temporary migrant workers through the COVID19 pandemic. The theoretical framing of the article draws on racial capitalism to argue that the developments manifest during the 'crisis times' of COVID-19 are in large part a continuity of the exclusionary politics of bordering practices at the heart of neoliberal capitalism. The article proposes that a rethinking of foundational theoretical and methodological approaches in the social sciences are needed to reflect contemporary changes in justice claims, claims that increasingly recognize the multi-species nature of existential threats to all life.
\end{abstract}

Keywords: migrants; refugees; human rights; humanitarianism; COVID-19; racial capitalism; neoliberalism

'They were the eateries that fed us The kilns that burned for us

They were the donkeys who carried the city's shit But when the lockdown came they were the unwanted Mere woodcutters and water carriers'

The Death-Walk Song (translation from Hindi)

(Vincent 2020)

\section{Introduction}

The spectre of death, illness, unemployment, recession and isolation wrought on the world by the global COVID-19 pandemic is, at least in some respects, ubiquitous and indiscriminate across global society. Yet, the effects of the virus and the evident divisions and inequalities experienced by vulnerable populations are exacerbated as a result of new national, regional and international measures taken in response to COVID19. Responses to COVID-19 can be assessed as exceptional actions taken in the extreme circumstances of the potential health crisis that the virus presents. Accordingly, states have responded by restricting or closing travel routes into and out of their territories (Halligan 2020); restricting social contact by closing workplaces, schools and non-essential activities (Storen and Corrigan 2020) and rolling out a raft of new state payments to businesses and individuals as 'bail-outs' for loss of economic activity (ATO 2021a, 2021b). Extending beyond a health crisis, COVID-19 has also precipitated an acknowledgement and perhaps the potential for a renewed awareness in some parts of global society of the need for care in the social realm, demonstrated by the implementation of large-scale economic and welfare interventions (IMF 2021). 
Since the official designation of the pandemic in March 2020 by the World Health Organization, restrictions on mobility, border closures and myriad other micro changes to rules, regulations and policies that relate to access to healthcare, social welfare provisions, the right to work and other 'basic rights' are now evident in most states across the globe. Accompanying these restrictions and measures is the political rhetoric by leaders of many nation-states, invoking a closed-border, citizens-only vision of who requires protection from the pandemic and forms of assistance to ameliorate the economic and social effects of pandemic interventions (Ramsari 2020). It is perhaps unsurprising that the mobility of persons and the core human rights ideal of people being able to 'carry bundles of rights' across nation-state borders is one of the first lines of attack when a perceived 'crisis' emerges (Collins 2019; Tazreiter 2019a). It is precisely the conundrum of the limits and epistemic edges of humanitarianism and adherence to human rights values that we wish to discuss through the prism of actions and reactions to vulnerable non-citizens: refugees, asylum seekers and temporary migrants. Our aim is not to mount a thorough review or critique of humanitarianism or of human rights as a legal framework but rather to contribute to new thinking on the research agendas that the social sciences ought to prioritise in working toward global justice agendas. That is, the circumstances and responses to COVID-19 highlight this need. The situation for the world's most vulnerable populations including refugees and displaced persons has considerably worsened through the COVID-19 pandemic (Bündnis Entwicklung Hilft 2020). Suddenly, attention, funding and empathy has turned inward. Our focus here is to ask how global responses appear in light of core human rights values and humanitarian values and ideals. These values and ideals are grounded in the history of the inter-war period and the aftermath of the Second World War. Are they appropriate in the contemporary world? What are the conundrums that emerge in analysing the responses to COVID-19? Later in the article, a focus on the politics of care provides an important conceptual framing to consider these questions.

In this article, we propose to contribute to the thinking through a recalibration of social science research through robust debates to integrate perspectives and critique from decolonial approaches in re-examining the impacts of the neoliberal state and racial capital. The term racial capitalism stays true to its original meaning espoused in Cedric Robinsons seminal work, Black Marxism: The Making of the Black Radical Tradition. Robinson's text challenges the Marxist assertion that the introduction of capitalism was a radical negation from feudalism. Instead, Robinson argues that the racial order found in Western feudal society, infused into and thus affected the organisation of labour under capitalism (Robinson 2000, p. 2). In this framework, the 'racial, tribal, linguistic and regional' antagonisms extended into economic relations (Robinson 2000, p. 10), whereby race and racial discrimination and subjugation became the means by which capitalism reifies 'regional and cultural differences into races in order to structure social divisions between different forms of labour' (Kundnani 2021, p. 20). Indeed, the histories of racial capital remain embedded in value systems across societies and are expressed and manifest in the exclusions and vulnerabilities faced by many migrants. Our point in raising these theoretical concepts is to highlight continuities in the exclusions and discriminations that migrants and refugees face. Though contemporary crises such as the COVID-19 pandemic may appear unique or novel, we suggest that exceptionalist responses by states to crisis events draw on, but also create, moral panics that often use migrants as scapegoats for a range of social problems.

Ultimately, the intellectual labour of countering and revealing such exclusionary tendencies also includes humanitarian and human rights approaches and values. Needless to say, this is an expansive agenda that many researchers and thinkers are contributing to. Here, we make a modest claim to contributing to this thinking. The ideas we explore are set against the case study of the Australian state's responses to COVID-19, focused on the circumstances faced by vulnerable migrant populations. Our argument in regard to global responses to the coronavirus pandemic is articulated along three lines. First, that the histories of often unacknowledged exploitation, theft (of lands, resources, identities) of racial capital through colonial projects are key links to understanding and problematizing 
contemporary responses, policies and attitudes to all manifestations of the (false) binaries, insiders/outsiders.

Second, we examine the circumstances of refugees, asylum seekers and other vulnerable migrants as non-citizens, emphasising the political issues manifest in many local settings of groups deemed as outsiders (and potentially stripped of rights and visibility), depending on changing political circumstances and social attitudes.

Our argument here is that from a moral and social justice perspective, the treatment of the most vulnerable indicates the commitment to human rights values. Third, ultimately, a justice-oriented vision leads to the enactment of a global commons (commons of land, knowledge, technologies, healthcare, access to vaccines and so on) - requiring attitudes and values that recognize the shared vulnerability of human and indeed non-human life.

An existential crisis such as a pandemic focuses attention on what a society's core values are and how vulnerable persons who happen to live in a particular territorial jurisdiction are protected or ignored (Carens 2013; Zaretsky 2019; Khazan 2020). One of the stark anomalies COVID-19 responses have highlighted are the divisions between citizen and non-citizen. While these divisions have long been present in border politics, state responses to COVID-19, or in some cases, the use of COVID-19 as a pretext for introducing new exclusions, are evident in many parts of the world. The response of states and societies that consider themselves liberal democracies are surprising and at times troubling from humanitarian and human rights perspectives. The article turns first to the concept of borders, key to the governance of populations and forms of exclusion, before exploring the case studies of temporary migrants and refugees.

\section{Borders and Migrants}

The border is both a concept and idea, as well as manifesting in the materiality of the territorial boundaries of states that dominates the contemporary world and certainly the inter-state system that remains so dominant in regulating human mobility. In migration studies, the border defines territory and thereby the gatekeeping role of the state whether at land borders or airports, or indeed at the virtual technologized border. Yet, simultaneously, the concept does the cultural work of sifting and sorting affiliations, loyalties and social ties built across generations and often in defiance of the geographically fixed spatiality of the nation-state. New and transdisciplinary scholarship argues for the polysemy of borders as a coextensive concept that is physical, metaphysical and relational (Mezzadara and Neilson 2013). Adding complexity is the analysis of the border as membrane (Bauböck 2015; Tazreiter et al. 2016), or as 'paper barriers' through bureaucratic exclusion. Beyond the physical barrier of the territorial border, complex layers of law and bureaucratic procedures, enacted by the nation-state through regulation and exclusion, mediate the opportunities and barriers for migrants and further exacerbate preexisting exigencies (Bhatia 2020). New bordering techniques also relate to the 'non-places' and extra-territorial zones (Augé 1992), such as the zones that refugees are often subject to in seeking to cross borders and subject to 'capture' in detention, deportation and other forms of forced 'onward movement'. It is notable that the circumstances of health quarantine during the COVID-19 pandemic have given many people a small and momentary insight into the physical and psychological conditions of refugee detention (Loughnan 2020).

Despite the complex and heterodox manifestations of borders, when it comes to the most needy and vulnerable migrants, nation-states' reactions to attempted border crossings or to the arrival of refugees and asylum seekers, a war footing often holds, with language, rhetoric and interventions premised on invasion. From this war approach, states give themselves license to remove, incarcerate and punish refugees for their mode of arrival and for simply being present, as is evident across the EU, North America and notably in Australia (Grewcock 2013, 2017; Martin 2015; McAdam 2017; Gleeson 2016). These approaches are evidently also being imposed on other categories of migrants under the circumstances of COVID-19 where humanitarian and human rights values are also under attack. 


\section{The Circumstances of Migrant Workers, International Students and Other Non-Citizens in Extraordinary Times}

Migration is not an anomaly, but an integral aspect of life and therefore ought to be normalized rather than being a shock or crisis event. An increase in prevalence of temporary rather than permanent migration is evident in many parts of the world, due to complex factors including less permanent work, increasingly transnational intimate and social networks and the economic demand for a highly mobile, yet dispensable, workforce. While globalised economies are highly adaptive to these international forces, the consequences of flexibility and quick adaptation for individuals and social groups, contradictory signals and experiences are evident in accessing rights and membership by the same states that desire migrants (Tazreiter 2019b; Tazreiter et al. 2016).

Through the extraordinary times of COVID-19, a lack of minimal rights and protections (Shachar 2009) exacerbate the problems faced in everyday life (O'Sullivan et al. 2020). In these circumstances, citizens and permanent residents become "free riders" on the economic, social and cultural contributions temporary migrants make to host societies, without the expected corollary of access to adequate and reciprocal rights and shared benefits (Rubio-Marin 2000). Though it is outside of the scope of this article to provide comparative detail, a growing scholarship conceptualizes the rights and presence of marginalized temporary migrants, or "mobile labour", in countries such as Australia, calling for attention to the harm that temporary migration programs can cause without attention to sufficient formal and social rights (Castles 2011; Mares 2016, 2017; Hennebry et al. 2018; Collins 2019).

What the conditions and new measures introduced through the COVID-19 pandemic have highlighted are serious shortcomings in how temporary migrants as non-citizens as well as other categories of migrant/other are treated and, ultimately, how they are viewed as persons. This line of argument is developed later in exploring racial capitalism and its links with how the state governs populations. Temporary entry visas and many categories of migrants-including workers and students, but also refugees-points to the need for new migration governance tools, but importantly for a new vision of global justice that challenges the limited view of humanitarianism and human rights values as inferior to nation-state sovereignty, at least from the view of states. What are the human consequences of temporary status and a lack of formal belonging? The contradictions that a restrictive citizenship model poses are highlighted by the circumstances of vulnerable migrants. In the Australian case, such contradictions emerge through the lens of COVID-19 restrictions. A question for future research is whether COVID-19 provides a context for extending restrictions that were already favoured by liberal democratic countries such as Australia's long before the pandemic.

The treatment of non-citizen migrants presents a conundrum for contemporary societies under the conditions of neoliberal globalization. Though temporary migration and the irregular status often closely associated with temporariness are fundamental aspects of contemporary global transformations that require this nimble adaptability, the burdens resulting from legal, economic and sociocultural exclusions that result from contemporary bordering practices are largely borne by migrants (Mezzadara and Neilson 2013). In the globalised neoliberal system, states gesture toward upholding the human rights of all peoples, yet implement policies and legislation that create precarity and vulnerability, including through a lack of access to the rights framework people require for sustainable life.

Human rights values that rely on the centrality and priority of the person are flipped not only to favour states, but to effectively obliterate the dignity of the person held outside and, as in the arguments outlined above, sovereignty understood as only relating to the nation-state. Our key argument is that the treatment and exploitation of vulnerable migrants is structured not only to favour states but that the stripping back of rights is a quite deliberate aspect of state approaches. For example, the trend towards temporary migration in Australia and the state's reliance on this form of migrant labour has been further exacerbated since the outbreak of the COVID-19 pandemic and responses to it. This is evidenced in the closure of Australia's national borders (to entry and to exit) as one of 
the most restrictive responses to the pandemic in the world, as well as in the restrictions to support measures for non-citizens. Soon after Australia closed its national border in March 2020, the Prime Minister, Scott Morrison, urged non-citizens to go home, saying:

"As much as it's lovely to have visitors to Australia in good times, at times like this, if you are a visitor in this country, it is time ... to make your way home ... For those backpackers in Australia who are nurses or doctors, or have other critical skills that can really help us during this crisis, there will be opportunities ... but our focus and our priority is on supporting Australians and Australian residents with the economic supports that are available". (Gibson and Moran 2020)

Australia's Prime Minister, Scott Morrison, announced soon after closing Australia's international borders on 19 March, 2020 that a range of state funded payments to employers and individuals could be accessed. These benefits, called JobKeeper (paid to employers in order to keep workers) and JobSeeker (paid to individuals who lost their jobs) ${ }^{1}$ were made available to Australian citizens and permanent residents, while an estimated 1.1 million temporary migrants were ruled ineligible. In numerous press conferences and public statements, the Prime Minister stressed the need to support Australians and the fairness of this in relation to care about use of taxpayer public funds. Many researchers and activists pointed out the problems with such an approach as Australia relies on high numbers of temporary migrants, including international students who work and pay taxes while living in Australia. The impoverishment of many temporary migrants living in Australia became evident as casual and part-time work in service sectors experienced large job losses from March with the imposition of 'lock-downs' where businesses were mandated not to open and individuals were restricted in their movements. The additional impacts of COVID-19 and related restrictions upon temporary non-citizens in Australia have been borne out in myriad ways and are continuing to do so. Meanwhile, population growth in Australia for 2021 was forecast to be the lowest since 1916-1917, at only $0.6 \%$, due in large part to the closure of the international border to migrants ${ }^{2}$ (ABC 2020).

Without the support of the state benefits of Jobkeeper and Jobseeker, temporary migrants face destitution, already witnessed throughout 2020, as concerned residents set up soup kitchens and other local interventions for those on temporary visas. As Matt Kunkel of the Migrant Workers Centre in Melbourne states, "This government has continually made decisions at every step of this response of this pandemic to cut them out of any sort of support at all" (Stayner 2020).

The article turns now to briefly outline the circumstances that refugees face in the Australian context and how COVID-19 responses have impacted on particular vulnerabilities that refugees face.

\section{The Treatment of Refugees-A Brief Overview of the Australian Context}

As a country of immigration, Australia has a long history of a bureaucratic, government led selection of immigrants according to specific categories that align with visa classes such as skilled immigrants, family reunion immigrants, humanitarian and refugee immigrants, as well as short-term migrant workers and international students (Jupp 2011). The state, intent on immigration control, does no deal well with spontaneous arrivals that disrupt this orderly approach to immigration (Crock 1998; Tazreiter 2017). Before turning to the responses to refugees during the COVID-19 pandemic, we outline briefly a background to Australia's recent refugee policy. Since 13 August 2012, asylum seekers arriving in Australia by boat without authorisation (a valid visa) have been subject to 'offshore' or 'third country' processing on Nauru or Manus Island in Papua New Guinea (PNG). Australia first introduced 'offshore processing' in Nauru and PNG in 2001, under what was called the 'Pacific Solution'. Offshore processing was suspended under the Labor government of Prime Minister Kevin Rudd in late 2007 and resumed again by the Labor government of Prime Minister Julia Gillard in August 2012. This policy has continued under successive conservative Liberal-National coalition governments since that time. Off-shore processing means that asylum seekers are forcibly transferred to Nauru or PNG and undergo a refugee 
status determination process in those countries (Penovic and Dastyari 2007). This policy has received considerable negative scrutiny both within Australia and internationally as breaching human rights standards and the spirit of the 1951 Refugee Convention (Archbold 2015; Henderson 2014; McAdam 2013). The conditions and day-to-day circumstances in off-shore detention have also been further distanced from public scrutiny through the process of privatizing detention and service provision (Nethery and Holman 2016). The two places of offshore detention are Manus Island under the jurisdiction of Papua New Guinea, and Nauru, the latter being an independent island state.

Being in detention 'off-shore' means that people are effectively made invisible and forgotten through media and information blackouts that also include visa restrictions for lawyers and human rights organisations. Such developments do not occur in a vacuum. They are closely related to social attitudes to immigration and outsiders, to the dominant tropes of the nation and to the collective memories that are prioritised in these social and political processes. Arguably, these processes are exacerbated during 'crisis times' such as the current global pandemic, where empathy toward non-citizens such as refugees is at a low ebb. Human rights abuses occur in the Australia government's treatment of refugees and asylum seekers both 'onshore' in Australian and 'offshore' in Nauru and Manus Island (Pugliese 2004; Gleeson 2016; Tazreiter 2019a).

On the Australian mainland, refugees brought to Australia from Nauru and Manus Island have been held in Alternative Places of Detention, including 'hotel detention' for long periods of time, with heightened health risks since the outbreak of COVID-19 (Holt and Vasefi 2020). Living in APOD's and Detention Centres meant that social distancing measures could not be adhered to due to overcrowding (Farhart 2020). Furthermore, the incarceration of non-citizens in Australia became visible during COVID-19, leading refugees, non-citizens and citizens to (peacefully) protest at the Mantra and Kangaroo Point Hotels (Vogl et al. 2020). Some refugees were released while others remain held. The seemingly arbitrary nature of these decisions is psychologically stressful for refugees.

For refugees in PNG or on Nauru, health risks from COVID-19 are extreme. Here, we see another anomaly in human rights terms, with wealthy nations restricting access to the COVID-19 vaccines and the intellectual property of the vaccine formula. After much global debate and shaming, wealthy nations, including Australia, agreed to make vaccines and the vaccine formula available to poorer countries, including India, where the outbreak of COVID-19 is causing catastrophic conditions with a lack of oxygen and other supplies in hospitals and a lack of firewood to cremate the deceased (Roy 2021).

In the past two Federal budgets, the Australian government has cut the humanitarian intake of refugees by 5000 places in each successive year (Refugee Council of Australia 2021), extending for the next five years. At the same time, the funding for offshore migration was allocated over USD 811 million although 238 people remain offshore in Nauru and PNG (Refugee Council of Australia 2021).

Over many years, the Australian government has implemented measures and legislation that separates refugee families, often through complex processes that effectively punish individuals for mode of arrival. The Human Rights Law Centre report 'Families left behind' illustrates the harm done to individuals and families by policies that deliberatively separate families for years and deny access to family reunion (HRLC 2020). The so-called 'Ministerial Direction 80' mandates that visa applications for family members of people who arrived by boat are given 'lowest processing priority' (HRLC 2020, p. 8). The outcome of this direction is that thousands of people living in Australia with refugee status are prevented from reuniting with family members as their applications sit at the bottom of a bureaucratic pile and are in effect never processed. The report details case studies that show the impact for individuals and families of policies that forcibly separate families, demonstrating a devastating impact on the mental health of adults and children who are in the care of the Australian Government (HRLC 2020).

The above examples of the new vulnerabilities faced by refugees and migrant workers indicate the politics of exclusion that are evidently exacerbated in the circumstances of 
COVID-19, indeed the COVID-19 pandemic provides a pretext in some cases for increasingly exclusionary measures. The fear of the global health pandemic has resulted in border closures and lock downs. However, importantly, empathy for and the visibility of the circumstances of vulnerable migrants has, in many instances, diminished or been hidden in the face of an inward focus - care and worry for self, for nation (Ferdinand et al. 2020). With this context in mind, we ask what a politics of care in a post-COVID-19 world might look like. How can the social relations of care, as well as the care economy, serve social transformation?

\section{The Politics of Care and the Care Economy}

Many scholars acknowledge the relationship between the market economy and the care economy. Indeed, care is recognised as a foundation for social life that all social relations rely on (Fine 2005, p. 253). In reaction to the deprivations experienced in the neoliberal public sphere, over time, the ethics of care became associated within the private sphere as a 'safety net', where one can find 'emotional refuge in a cold and competitive society' (Lasch 1976, p. 44).

Embedded in the neoliberal context that devalues 'care work' and subsequently fragments structures and feelings of care, care is intimately linked with normative understandings of family and of gendered roles (Daly and Lewis 2003; Held 1987). The devaluation and invisibility of 'care work' in the neoliberal context characterises the (productive) market economy (masculine) that in turn ignores the (reproductive) care economy (feminine). Those that labour, usually unpaid, in care-work also sustain the highly inequitable productive processes of capital, being meanwhile paradoxically and disproportionately affected by the same relations (Fraser 2016a, 2016b). Nancy Fraser argues, though, that capitalist society is today experiencing a 'crisis of care' (Fraser 2016b). Fraser's theory of care rests on the process of individualisation that precipitates a paradox of freedoms. At the heart of liberal rationality, a contradiction emerges that 'both extends and restricts freedom' (Polanyi 2001, p. 262). A market economy produces two types of freedoms: those foundational 'actual' freedoms derived from liberalism and 'evil' freedoms that emerge from the reformation of regulation at the expense of security (Polanyi 2001). The once divided partition between 'formal' and 'informal' care work, sustained by dominant stereotypes of women as 'good' wives and mothers and grounded in the division between paid and unpaid work, disappeared over time (Daly and Lewis 2003, p. 284; Fine 2005, p. 248). In the Australian context, Barbara Pocock defines the crisis of care as a 'fallout' that intersects 'between spheres of work, gender relations, consumption, community and family', whereby the availability of care is diminished by the changing and unchanging spheres of the Work/Life collision (Pocock 2003, p.1), emphasis in original). Analysing social reproduction for the focus of this paper on migrant labour provides a conceptual framework and a lens to examine sources of wealth and inequality in society, that is human life and human labour (Jaffe 2020). These analyses articulate the necessity of unremunerated social reproduction, and hence the dependency upon exploited labour, concerning the production of capital.

The vulnerable and precarious circumstances of temporary migrants and refugees in Australia has not only been made increasingly visible, but has also been amplified by the COVID-19 pandemic (Dehm et al. 2021; Vogl et al. 2020), demonstrating how the state has eschewed responsibility for social reproduction as care-work in relation to vulnerable migrants. As outlined earlier, the first confirmed case of COVID-19 in Australia was identified on 25 January 2020 (Hunt 2020). On 20 March 2020, the borders closed to all nonresidents, and subsequently, states and territories began to close all 'non-essential' services the following day. Correspondingly, the government began implementing Social Distancing Guidelines, ultimately requiring individuals to stay home and isolate (Department of Health 2020). The subsequent effects of the COVID-19 pandemic estimate shut-downrelated job losses in the range of 14 to $25 \%$ (Coates et al. 2020).

On 3 April 2020, the Australian Government further exacerbated and augmented pre-existing vulnerabilities of temporary migrants through their exclusion from the Com- 
monwealth safety net, the Coronavirus supplement (Whiteford 2020), in which the government claimed they had to 'draw the line somewhere' (Cash 2020). Exclusionary and divisive rhetoric encouraging temporary migrants to 'go home' was also used (Coleman 2020). With the exemption of New Zealanders on the temporary 444 visas, the remaining estimated 1.1 million temporary migrants were excluded from the JobKeeper and JobSeeker welfare assistance packages based on their visa status (Stayner 2020). The first incarnation of assistance packages for 'Australian's only' has not only been categorised as unethical but was also deemed to breach fundamental human rights regarding Equal Rights at Work under international conventions, thereby undermining Australia's Fair Work Act (Tham 2020). Government assistance towards temporary migrants has been oriented towards helping the nation rather than the migrant. The extension of working rights to 40 hours per week (previously $21 \mathrm{~h}$ per week) for international students employed as aged-care workers, disability workers and nurses, alongside those employed in Australia's major supermarkets 'to help keep Aussie shelves stocked' (Tudge 2020), is predicated on two notions. Firstly, a fundamentally self-interested state, and secondly, the recognition of the necessity of temporary migrants to fundamental work roles in Australian society during the pandemic. Consequently, due to the conditions of the JobKeeper payment, employers were forced to stand down temporary migrants due to their ineligibility for the payment as non-citizens and instead retain other eligible workers such as Australian citizens and permanent residents (Karp 2020).

A large-scale survey of temporary visa holders, conducted by Unions NSW (2020), claims that the circumstances of temporary migrants in Australia has resulted in a 'humanitarian crisis'. The data shows that $65 \%$ of participants lost their job; $87 \%$ were experiencing difficulty paying their weekly expenses; $43 \%$ were skipping meals on a regular basis; $34 \%$ were already homeless, or anticipated imminent eviction; and 39\% did not have enough money to cover basic living expenses (Unions NSW 2020). According to the Settlement Services International's (SSI) Temporary Visa Holder Survey measuring hardship faced during COVID- $19^{3}$, similar results were found with $82 \%$ of survey participants 'had lost job or [had] work hours reduced'; $75 \%$ 'could not pay the rent or mortgage on time'; $52 \%$ 'could not buy medicine' that was normally taken; 50\% 'could not access health services' that were needed; and $62 \%$ went 'without meals because [they] didn't have enough money' (SSI 2020).

With a lack of Federal Government support for temporary visa holders living in Australia after the outbreak of COVID-19, responsibility fell on state governments and universities to provide financial support (Doherty et al. 2020), alongside an overwhelmed civil society sector that has reported a dramatic increase in temporary migrants, asylum seekers and refugees requiring assistance (Asylum Seeker Resource Centre 2020; Life without Barriers 2020; Refugee Council of Australia 2020). Furthermore, demand for emergency food has risen roughly $50 \%$ since the pandemic, which, according to Foodbank Australia, amounts to more than a million people per month-with much of the demand coming from international students and temporary migrant workers (Schneiders and Millar 2020). A recent survey conducted by Berg and Farbenblum (2020) identifies the amplification of financial, physical and psychological damage during COVID-19. Notably, abuse and violence at home, exploitative work conditions and experiences of racism, abuse and harassment increased. Accordingly, participant responses from this study used stark and dehumanising language to describe their current situation: 'they don't see us. They can't hear us', 'like we do not exist', 'like I didn't matter" (Berg and Farbenblum 2020, p. 90). Moreover, to describe their position in the Australian society, respondents used language such as: 'ATMs of the Australian government', 'just money, otherwise we are not worth anything' (Berg and Farbenblum 2020, p. 9).

In terms of the exclusion of temporary migrants from support in the form of welfare packages, we suggest that COVID-19 is not merely a health crisis but is also a reflection and amplification of systematic forms of economic and social inequality, undermining the complex and intersecting social relations that society is built on. The mistreatment of 
temporary and vulnerable migrants is perceived as symptomatic of deep and systematic forms of discrimination, the result of historical processes embedded in racial capital and in settler-colonial societies such as Australia. The article now considers these ideas.

\section{Justifications for Exclusion and Exception}

The case study of Australia's response to migrants and refugees in COVID-19 times provides the context against which we now consider the historical antecedents of exclusion and border practices. To contextualise the evidence of cruelties and austerity practiced onshore and offshore toward asylum seekers explored later in the chapter, we first consider the persistence of the colonial imaginary in the contemporary nation-state. This colonial imaginary extends to the present, often expressed in racism observable as the systematised devaluation of some humans. Importantly, the deeply embedded value system that undergirds racialisation extends to many forms of 'difference' through highlighting the fundamental charateristics of people. Racialisation takes many forms, perhaps most commonly in state implemented policies, laws and administrative measures of dividing and categorising populations. The processes of racialisation evident in the creation of hierarchies of humans are manifest and driven by the technologies of the state. This racialisation is evident in the processes of dividing, categorising and stigmatising humans according to a range of biological and/or acquired qualities and characteristics used in regimes of power to dominate and to marginalise (Mignolo 2011; Weheliye 2014). Racialisation relies on a range of techniques that draw on embodied characteristics of persons (such as gender, disability, sexual preference) and to target such fundamental aspects of personhood for exclusion. Racialisation occurs where biological or cultural characteristics are equated with values and qualities attached selectively to some persons in creating divisions and hierarchies of deserving or 'better' persons. Such divisions and hierarchies are drawn on, whether consciously or unconsciously, in decision making on policies and resource allocation. Such hierarchies, and the categories that result in the bureaucracies of the state, have the effect of allocating differential value to persons.

Historically, the institutions of the state, such as the institutions of health, education, police, prisons and asylums, have administered the segregation, punishment and removal of minority groups and outsiders based on a range of criteria and hierarchies such as race, ethnicity, religious and political affiliations, sexual orientation and physical and mental disability. A 'politics of eugenics' (Spektorowski and Ireni-Saban 2013) underlies these schemes with policies and social attitudes that drive and validate a hierarchy of humans. Such coercive policies and actions, evident in many parts of the contemporary world, politicise life, resulting in 'social death' and 'slow death' (Nixon 2011), as well as the annihilation of targeted populations through medical, scientific and bureaucratic specialisation (Foucault 1997, 2003; Arendt 1951; Agamben 1998; Berlant 2011).

The signals that systems of administration, enforcement and also care (such as healthcare) send are interpreted through bodily and emotional reactions as well as cognitive or 'rational' responses. Moreover, these systems leave traces and marks on the body, often quite deliberately, as discipline. This governance of the body (biopolitics) is manifest and visible in many domains, but prominently in migration governance, particularly where migration is 'irregular' and not determined and controlled by the state. This form of migration encounters a punitive response by the Australian government, as the 'irregularity' is perceived as uncompliant. For a settler-colonial state such as Australia, the still unresolved traumas and violence directed at Indigenous Australians through the period and the processes of colonisation echo in contemporary Australian social and political life (Lake and Reynolds 2008). A continuity from the past to the present can be traced where the abject lives of asylum seekers as well as forgotten migrant workers are tolerated as part of a colonial mentality where a hierarchy of ruled, abject people must be maintained. A critique of the colonial values and imagination that persist in contemporary nation-states, often expressed in racism and exclusion, is observable as systematised devaluation of some humans. The responses to the COVID-19 pandemic reveal such a hierarchy of humans 
and of value attached to persons, be it in access to vaccines or in access to 'safety' and basic survival.

Intersectional analysis that recognises the reality of multiple and overlapping identities pushes these theories further, eschewing the orthodoxies that entrench social attitudes, law and public policy and the categorisations attached to identity markers (Yuval Davis 2011) significantly to biopolitical markers such as race, gender, ethnicity and disability. What many writers and theorists seek to highlight are the entrenched, seemingly naturalised hierarchies of persons that attach differential value to persons based on biological characteristics or cultural difference. The violence of biopolitical hierarchies of persons enacted through state policies operate through the logic of the sovereign entity of the nation-state, protecting a selected population of citizens and residents through the exclusion and erasure of other populations deemed troublesome.

\section{Visions of Justice beyond Humanitarianism and Human Rights}

The state-instituted practices of segregation and exclusion explored above are evidently manifest in extreme forms for vulnerable migrants. In this article, the evidence of the circumstances of refugees and migrant workers during increased border controls and austerity imposed due to the COVID-19 pandemic highlight both particular forms of discrimination and human rights abuses, while also indicating a continuity of abusive practices. As we have argued, the concept of border and bordering practices are utilised by states to segregate and also punish certain populations, drawing on historically embedded legacies of colony and empire. These legacies, which rely on a hierarchy of humans that devalues the lives of some persons, are core aspects of racial capitalism that the state draws on and utilises.

Migrants are often considered by the state as labour but not as potential citizens-their use value is their labour, and without citizenship status, their humanity and equal status as human is diminished. The circumstances of COVID-19 have exacerbated the restrictions imposed on temporary migrants in the Australian case, highlighting the stark exclusions that non-citizenship status brings. The circumstances of refugees and asylum seekers are even more stark, with the politics of exclusion and the lived experience of 'rightlessness' resulting in abject life.

The root of dignity of the person rests on the recognition of the inherent, non-tradeable qualities of an individual (Benhabib 2011). In contemporary human rights language, this is referred to as the inalienability of rights in how any person is treated, whether through social, political or economic systems of meaning making or of exchange. What we have described in this article through the case studies of the Australian state's treatment of vulnerable migrants is the lived experience of an abject life, lived in the shadows with experiences of shame and humiliation, emotions anathema to human dignity (Sedgwick and Frank 1995; Zolkos 2010). The core values of dignity of the person inherent in human rights and the impetus for humanitarian action appear to be absent or superseded by nationalist impulses highlighted in the responses to COVID-19.

Although it is outside the remit of this article to take these ideas more deeply into the realm of new research agendas for the social sciences, we wish to end our discussion urging more active debate and commitments across research fields from the starting point of valuing research and access to education and knowledge as a basic right. Further conceptual elaboration of new epistemological and methodological thinking to guide social science research is needed-beyond the humanitarian and human rights values that themselves remain embedded in classical liberalism and the histories of racial capitalism, tied to neoliberalism. As we argued earlier in the article, researchers and analysts ought to be alert to the consequences of exclusions and restrictions imposed in pandemic circumstances. Many scholars and activists work toward elaborating new futures, drawing, for example, on multispecies recognition of common existential threats and also solutions to those threats beyond the human-centred, inter-state system of the post-WWII era. Ultimately, it is 
likely to be action and demands from the grass roots, from civil society in diverse locations, that can exert pressure on states and corporations for new approaches.

Author Contributions: Conceptualization, C.T. and S.M.; methodology, C.T. and S.M.; validation, C.T. and S.M.; formal analysis, C.T. and S.M.; investigation, C.T. and S.M.; writing-original draft preparation, C.T. and S.M.; writing-review and editing. C.T. and S.M.; visualization, C.T. and S.M.; supervision, C.T. and S.M.; All authors have read and agreed to the published version of the manuscript.

Funding: This research received no external funding.

Data Availability Statement: Not applicable.

Conflicts of Interest: The authors declare no conflict of interest.

\section{Notes}

1 Source: https://www.servicesaustralia.gov.au/individuals/news/how-jobseeker-payment-different-jobkeeper-payment (accessed on 5 September 2021).

2 See also latest figures (though only for first quarter of 2020)—https://www.aph.gov.au/About_Parliament/Parliamentary_ Departments/Parliamentary_Library/FlagPost/2020/June/COVID_and_temporary_migration (accessed on 5 September 2021). Survey involved 461 participants who held a temporary humanitarian or bridging visa. May 2020.

\section{References}

ABC. 2020. Federal Treasurer Forecasts Difficult Economic Recovery after Coronavirus Recession Amid Slump in Population Growth, Low Interest Rates. ABC News, July 24. Available online: https:/ /www.abc.net.au/news/2020-07-24/treasurer-josh-frydenbergbaby-boom-economy-recovery-coronavirus/12489678 (accessed on 5 September 2021).

Agamben, Giorgio. 1998. Homo Sacer: Sovereign Power and Bare Life. Stanford: Stanford University Press.

Archbold, Lisa Jane. 2015. Offshore processing of asylum seekers-Is Australia complying with its international legal obligations? QUT Law Review 15: 137-58. [CrossRef]

Arendt, Hannah. 1951. The Origins of Totalitarianism. Orlando: Harcourt Publishing.

Asylum Seeker Resource Centre. 2020. ASRC Submission to COVID19 Senate Inquiry Exposes Extreme Vulnerability Due to Government Neglect. Available online: https:/ /www.asrc.org.au/2020/06/01/asrc-submission-to-covid19-senate-inquiryexposes-extreme-vulnerability-due-to-government-neglect/ (accessed on 5 September 2021).

ATO. 2021a. Support for Individuals and Employees. Commonwealth of Australia. Canberra. Available online: https:/ /www.ato.gov. $\mathrm{au} /$ General/COVID-19/Support-for-individuals-and-employees/ (accessed on 5 September 2021).

ATO. 2021b. Support for Businesses and Employers. Commonwealth of Australia. Canberra. Available online: https:/ /www.ato.gov. au/General/COVID-19/Support-for-businesses-and-employers/ (accessed on 5 September 2021).

Augé, Michel. 1992. Non-Places: Introduction to an Anthropology of Supermodernity. Translated by John Howe. London: Verso.

Bauböck, Rainer. 2015. Rethinking borders as membranes. In Rethinking Border Control for a Globalizing World. Edited by Leanne Weber. London: Routledge.

Benhabib, Seyla. 2011. Dignity in Adversity. Human Rights in Troubled Times. Cambridge: Polity Press.

Berg, Laurie, and Bassina Farbenblum. 2020. As If We Weren't Humans: The Abandonment of Temporary Migrants in Australia during COVID-19. New South Wales: MWJI.

Berlant, Lauren. 2011. Cruel Optimism. Durham and London: Duke University Press.

Bhatia, Monish. 2020. The Permission to be Cruel: Street-Level Bureaucrats and Harms against People Seeking Asylum. Critical Criminology 28: 277-92. [CrossRef]

Bündnis Entwicklung Hilft. 2020. World Risk Report: Forced Displacement and Migration. Berlin: Bündnis Entwicklung Hilft.

Carens, Joseph. 2013. The Ethics of Immigration. Oxford: Oxford University Press.

Cash, Michaelea. 2020. The Senate Questions without Notice JobKeeper Payment: Question. In Parliamentary Debates; Canberra: Commonwealth of Australia. Available online: https:/ / parlinfo.aph.gov.au/parlInfo/search/display/display.w3p;db=CHAMBER; $\mathrm{id}=$ chamber\%2Fhansards\%2Ff7febdd5-d88f-4196-b9d3-3015db29c96b\%2F0030;query=Id\%3A\%22chamber\%2Fhansards\%2Ff7 febdd5-d88f-4196-b9d3-3015db29c96b\%2F0100\%22 (accessed on 5 September 2021).

Castles, Stephen. 2011. Migration, crisis, and the global labour market. Globalizations 8: 311-24. [CrossRef]

Coates, Brendan, Matt Cowgill, Tony Chen, and Will Mackey. 2020. Shutdown: Estimating the COVID-19 Employment Shock. Edited by Grattan Institute. Available online: https:/ / grattan.edu.au/wp-content/uploads/2020/04/Shutdown-estimating-the-COVID-19 -employment-shock-Grattan-Institute.pdf (accessed on 5 September 2021).

Coleman, David. 2020. Coronavirus and Temporary Visa holders In Home Affairs Potrfolio; Canberra: Australian Government.

Collins, Jock. 2019. Migration to Australia in Times of Crisis. In The Handbook of Migration Crises. Edited by Menjivar Cecilia, Ruiz Marie and Ness Immanuel. Oxford: Oxford University Press, pp. 817-31. 
Crock, Mary. 1998. Immigration and Refugee Law in Australia. Leichardt: Federation Press.

Daly, Mary, and Jane Lewis. 2003. The concept of social care and the analysis of contemporary welfare states. British Journal of Sociology 51: 281-98. [CrossRef] [PubMed]

Dehm, Sara, Claire Loughnan, and Linda Steele. 2021. COVID-19 and sites of confinement: Public health, disposable lives and legal accountability in immigration detention and aged care. UNSW Law Journal 44: 60-93.

Department of Health. 2020. Physical Distancing for Coronavirus (COVID-19); Canberra: Australian Government.

Doherty, Ben, Josh Taylor, and Paul Karp. 2020. Left with nothing': Australia's migrant workforce face destitution without coronavirus safety net. The Guardian, April 1. Available online: https:/ /www.theguardian.com/australia-news/2020/apr/01/left-withnothing-australias-migrant-workforce-face-destitution-without-coronavirus-safety-net (accessed on 5 September 2021).

Farhart, Claudia. 2020. Asylum Seekers Lodge Complaint with Ombudsman over 'Catastrophic' Coronavirus Concerns. SBS News, May 7. Available online: https:/ / www.sbs.com.au/news/asylum-seekers-lodge-complaint-with-ombudsman-over-catastrophiccoronavirus-concerns (accessed on 5 September 2021).

Ferdinand, Angelina, Claire Loughnan, and Philomena Murray. 2020. Refugees and Australia's Double Standards on Covid-19'. Arena Online, June 16. Available online: https:/ / arena.org.au/refugees-and-australias-double-standards-on-covid-19/ (accessed on 5 September 2021).

Fine, Michael. 2005. Individualization, risk and the body: Sociology and care. Journal of Sociology 41: 247-66. [CrossRef]

Foucault, Michel. 1997. The Birth of Biopolitics. In Ethics, Subjectivity, and Truth. Edited by Paul Rabinow and J. D. Fubion. New York: New Press, pp. 73-79.

Foucault, Michel. 2003. Society Must be Defended. Lectures at the College de France 1975-1976. Translated by D. Macey. New York: Picador.

Fraser, Nancy. 2016a. Contradictions of Capital and Care. New Left Review 100. Available online: https:/ / www.newleftreview.org/ issues/ii100/articles/nancy-fraser-contradictions-of-capital-and-care (accessed on 5 September 2021).

Fraser, Nancy. 2016b. Capitalism's Crisis of Care. Dissent 63: 30-37. [CrossRef]

Gibson, Jano, and Alexis Moran. 2020. 'As coronavirus spreads, 'it's time to go home' Scott Morrison tells visitors and international students'. ABC News, April 3. Available online: https:/ /www.abc.net.au/news/2020-04-03/coronavirus-pm-tells-internationalstudents-time-to-go-to-home/12119568 (accessed on 5 September 2021).

Gleeson, Madeleine. 2016. Offshore: Behind the Wire on Manus and Nauru. Sydney: Newsouth.

Grewcock, Michael. 2013. Australia's ongoing border war. Race E Class 54: 10-32.

Grewcock, Michael. 2017. “Our lives is in danger": Manus Island and the end of asylum. Race E Class 59: 1-20.

Halligan, John. 2020. Australia's Response to the COVID-19 Pandemic. Good Public Governance in a Global Pandemic 1: $233-46$.

Held, Virginia. 1987. Feminism and Moral Theory. In Bioethics: An Introduction to the History, Methods, and Practice. Edited by Nancy S Jecker, Nancy Ann Silbergeld Jecker, Nancy C. Jecker, Albert R. Jonsen and Robert A. Pearlman. Burlington: Jones and Barlett Publishers, pp. 152-58.

Henderson, Claire. 2014. Australia's Treatment of Asylum Seekers: From Human Rights Violations to Crimes Against Humanity. Journal of International Criminal Justice 12: 1161-118. [CrossRef]

Hennebry, Jenna, K. C. Hari, and Nicola Piper. 2018. Not without them: Realizing the sustainable development goals for women migrant workers. Journal of Ethnic and Migration Studies 45: 2621-37. [CrossRef]

Holt, Rebekah, and Saba Vasefi. 2020. 'We Are Sitting Ducks for Covid 19': Asylum Seekers Write to PM after Detainee Tested in Immigration Detention. The Guardian, March 24. Available online: https://www.theguardian.com/australia-news/2020/mar/24 /we-are-sitting-ducks-for-covid-19-asylum-seekers-write-to-pm-after-detainee-tested-in-immigration-detention (accessed on 5 September 2021).

Human Rights Law Centre. 2020. Families Left behind: Submission to the ANAO's Audit of International Travel Restrictions during COVID-19. Melbourne: Human Rights Law Centre Ltd.

Hunt, Greg. 2020. First Confirmed Case of Novel Coronavirus in Australia; Canberra: Department of Health, Australian Government.

IMF (International Monetary Fund). 2021. Policy Responses to COVID-19, Regional Economic Outlook. Washington, DC: International Monetary Fund.

Jaffe, Sarah. 2020. Social Reproduction and the Pandemic, with Tithi Bhattacharya. Dissent (blog), April 2. Available online: https:/ / www.dissentmagazine.org/online_articles/social-reproduction-and-the-pandemic-with-tithi-bhattacharya (accessed on 5 September 2021).

Jupp, James. 2011. Politics, public policy and multiculturalism. In Multiculturalism and Integration: A Harmonious Relationship. Edited by James Jupp and Michael Clyne. Canberra: ANU E-Press, pp. 41-52.

Karp, Paul. 2020. Sydney Laundry Condemned for Standing Down Migrant Workers Ineligible for Jobkeeper. The Guardian. Available online: https: / / www.theguardian.com/australia-news/2020/apr/30/sydney-laundry-condemned-forstanding-down-migrantworkers-ineligible-for-jobkeeper (accessed on 5 September 2021).

Khazan, Olga. 2020. How the Coronavirus Could Create a New Working Poor. The Atlantic, April 15.

Kundnani, Arun. 2021. The racial constitution of neoliberalism. Race $\mathcal{E}$ Class, 63. [CrossRef]

Lake, Marion, and Henry Reynolds. 2008. Colour Bar: The International Challenge of Racial Equality. Cambridge: Cambridge University Press.

Lasch, Christopher. 1976. The Family as a Haven in a Heartless World. Salmagundi 35: 42-55.

Life without Barriers. 2020. How We're Supporting People in Our NISS Services during COVID-19. Rockdale: Life Without Barriers.

Loughnan, Claire. 2020. Not the Hilton. Arena Quarterly 3: 39-46. 
Mares, Peter. 2016. Not Quite Australian. How Temporary Migration Is Changing the Nation. Melbourne: Text Publishing.

Mares, Peter. 2017. Locating Temporary Migrants on the Map of Australian Democracy. Migration, Mobility, E Displacement 3: 9-31.

Martin, Greg. 2015. Stop the boats! Moral panic in Australia over asylum seeker. Continuum: Journal of Media E Cultural Studies 29: 304-22.

McAdam, Jane. 2013. Australia and Asylum Seekers. International Journal of Refugee Law 25: 435-48. [CrossRef]

McAdam, Jane. 2017. The enduring relevance of the 1951 Refugee Convention. International Journal of Refugee Law 29: 1-9. [CrossRef]

Mezzadara, Sandro, and Brett Neilson. 2013. Border as Method, or, the Multiplication of Labor. Durham: Duke University Press.

Mignolo, Walter. D. 2011. The Darker Side of Western Modernity: Global Futures, Decolonial Options. Durham: Duke University Press.

Nethery, Amy, and Rosa Holman. 2016. Secrecy and human rights abuse in Australia's offshore immigration detention centres. The International Journal of Human Rights 20: 1018-38. [CrossRef]

Nixon, Rob. 2011. Slow Violence and the Environmentalism of the Poor. Cambridge: Harvard University Press.

O'Sullivan, Dominic, Mubarak Rahamathulla, and Manohar Pawar. 2020. The impact and implications of COVID-19: An Australian perspective. The International Journal of Community and Social Development 2: 134-51. [CrossRef]

Penovic, Tania, and Azadeh Dastyari. 2007. Boatloads of incongruity: The evolution of Australia's offshore processing regime. Australian Journal of Human Rights 13: 33-61. [CrossRef]

Pocock, Barbara. 2003. The Work/life Collision: What Work Is Doing to Australians and What to Do about It. Sydney: Federation Press.

Polanyi, Karl. 2001. The Great Transformation: The Political and Economic Origins of Our Time. Boston: Beacon Press.

Pugliese, Josephß. 2004. Subcutaneous law: Embodying the Migration Amendment Act 1992. Australian Feminist Law Journal 21: 23-34. [CrossRef]

Ramsari, Atefeh. 2020. The rise of the COVID-19 pandemic and the decline of global citizenship. In COVID-19. London: Routledge, pp. 94-105.

Refugee Council of Australia. 2020. Community Health at Risk If Temporary Visa Holders Left Unprotected. Available online: https:/ / www.refugeecouncil.org.au/community-health-at-risk-if-temporary-visa-holders-left-unprotected/ (accessed on 5 September 2021).

Refugee Council of Australia. 2021. The Federal Budget: What It Means for Refugees and People Seeking Humanitarian Protection. Available online: https:/ / www.refugeecouncil.org.au/federal-budget-what-it-means-for-refugees-and-people-seekinghumanitarian-protection/ (accessed on 5 September 2021).

Robinson, Cedric. J. 2000. Black Marxism: The Making of the Black Radical Tradition. Chapel Hill: The University of North Carolina Press.

Roy, Arundhati. 2021. 'We are witnessing a crime against humanity': Arundahati Roy on India's Covid catastrophe. The Guardian, April 28.

Rubio-Marin, Ruth. 2000. Immigration as a Democratic Challenge: Citizenship and Inclusion in Germany and the United States. Cambridge: Cambridge University Press.

Schneiders, Ben, and Royce Millar. 2020. Starved Out of Australia: The Workers without Money or Food. The Sydney Morning Herald. Available online: https:/ / www.smh.com.au/national/starved-out-of-australia-the-workers-without-money-or-food-202004 29-p54o8u.html (accessed on 5 September 2021).

Sedgwick, Eve. Kosofsky, and Adam Frank, eds. 1995. Shame and Its Sisters: A Silvan Tomkins Reader. Durham and London: Duke University Press.

Shachar, Ayelet. 2009. The Birthright Lottery. Citizenship and Global Inequality. Cambridge: Harvard University Press.

Spektorowski and Ireni-Saban. 2013. Politics of Eugenics: Productionism, Population, and National Welfare. London: Routledge.

SSI (Settlement Services International). 2020. SSI Temporary Visa Holder Survey: Report on Findings. May 18. Available online: https://www.ssi.org.au/images/websiteimages/news/2020/May/Impact_of_Covid-19_on_temporary_residents_in_ NSW_-_final_1.pdf (accessed on 5 September 2021).

Stayner, Tom. 2020. Australia's Temporary visa Holders Remain Locked out of Jobkeeper and Jobseeker. SBS News, July 21. Available online: https:/ / www.sbs.com.au/news/australia-s-temporary-visa-holders-remain-locked-out-of-jobkeeper-and-jobseeker/ 4a878a15-82d3-4f66-8343-d02f0587ef55 (accessed on 5 September 2021).

Storen, Rebecca, and Nikki Corrigan. 2020. COVID-19: A chronology of state and territory government announcements (up until 30 June 2020). In Research Paper Series, 2020-21. Canberra: Parliament of Australia, Department of Parliamentary Services.

Tazreiter, Claudia. 2017. Asylum Seekers and the State: The Politics of Protection in a Security-Conscious World. London: Routledge.

Tazreiter, Claudia. 2019a. Crisis politics of asylum seekers and migrant arrivals in Australia. In The Handbook of Migration Crises. Edited by Menjivar Cecilia, Ruiz Marie and Ness Immanuel. Oxford: Oxford University Press, pp. 619-34.

Tazreiter, Claudia. 2019b. Temporary migrants as an uneasy presence in immigrant societies: Reflections on ambivalence in Australia. International Journal of Comparative Sociology 6: 91-109. [CrossRef]

Tazreiter, Claudia, Leanne Weber, Sharon Pickering, Marie Segrave, and Helen McKernan. 2016. Fluid Security in the Asia Pacific. Transnational Lives, Human Rights and State Control. , London: Palgrave MacMillan.

Tham, Joo Cheong. 2020. The COVID-19 Crisis, Labour Rights and the Role of the State. Journal of Australian Political Economy 85: 71-83. Tudge, Alan. 2020. Joint Media Release with the Hon Dan Tehan MP-More Help to Keep Aussie Shelves Stocked; Canberra: Parliament of Australia. Available online: https://minister.homeaffairs.gov.au/davidcoleman/pages/more-help-aussie-shelves-stocked.aspx (accessed on 5 September 2021). 
Unions NSW. 2020. No Worker Left behind: Support Equal Access to Welfare for Temporary Migrants. NSW. Available online: https: //www.unionsnsw.org.au/wp-content/uploads/2020/08/NWLB_survey_results_aug_2020.pdf (accessed on 5 September 2021).

Vincent, N. 2020. Chavunadappattu/Death-Walk Song / मृत्यु-यात्रा गीत", Kochi: Phase One \& Uru Art Harbor. Available online: https: / / www.youtube.com/watch?v=MdL1kE1M02E (accessed on 1 September 2021).

Vogl, Anthea, Caroline Fleay, Claire Loughnan, Philomena Murray, and Sara Dehm. 2020. COVID-19 and the relentless harms of Australia's punitive immigration detention regime. Crime, Media, Culture: An International Journal 17: 43-51. [CrossRef]

Weheliye, Alexander G. 2014. Habeas Viscus: Racializing Assemblages, Biopolitcs, and Black Feminist Theories of the Human. Durham: Duke University Press.

Whiteford, Peter. 2020. Open Letter to the Prime Minister: Extend Coronavirus Support to Temporary Workers. The Conversation. Available online: https: / theconversation.com/open-letter-to-the-prime-minister-extend-coronavirus-support-to-temporaryworkers-135691 (accessed on 5 September 2021).

Yuval Davis, Nira. 2011. The Politics of Belonging: Intersectional Contestations. London: Sage.

Zaretsky, Robert. 2019. The Cure for the Plauge is Decency. For Times of Extremity, Albert Camus Prescribed Modest Virtues. Foreign Affairs, November 1.

Zolkos, Mary. 2010. Reconciling Community and Subjective Life. Trauma Testimony as Political Theorizing in the Work of Jean Amért and Imre Kertész. New York: Cotinuum Books. 